April 2018

\title{
Potensi Tumbuhan Xanthostemon novoguineensis Valeton (Myrtaceae) dalam Fitoteknologi
}

\author{
RAYNARD C. SANITO \\ Program Studi Teknik Lingkungan, Universitas Sains dan Teknologi Jayapura, Papua \\ Diterima: 13 Februari 2018 - Disetujui: 29 Maret 2018 \\ (C) 2018 Jurusan Biologi FMIPA Universitas Cenderawasih
}

\begin{abstract}
This article is essential in a further analysis that related with potential feasibility function of Xanthostemon novoguineensis in phytotechnology from one of an endemic plant in Papua, particularly in the remediation of polluted environment and the phytostructure of open green space area. This review aims to analyse the potential of this plant based on literature review and compare each research results towards some species from Myrtaceae family. X. novoguineensis may be cultivated on an open green space area in Papua due to complying suitable requirements. Those requirements are namely ecology function as a source of insect diets, social-cultural functions in represent culture, the the relationship among Papuan Ethnic and their nature, and aesthetic functions due to its beautiful flower. In addition, the plant has a potential in phytoremediation of polluted environment due to its adaptation ability in a dry soil condition. As the comparison, the phytostructure of open green space area context, $X$. chrysanthus has been cultivated on a public and private open green space area in Malaysia and Singapore. It has an important role as ecology function due to provide the source of food to many birds species undirectly. Owing to make the city landscape greater, the flower of X. chrysanthus, which has conspicuously and magnificently yellow colour, is a suitable plant to be cultivated. Furthermore, in the remediation assessment of polluted environment, $X$. chrysanthus has the abilities in adaptation on the dry environment. The range levels acid $(\mathrm{pH})$ of soil are 2-2.5. Interestingly, X. melanoxylon, which is an endemic species from Solomon Island, is growth naturally in an ultrafamic soils, consist of a high concentration of chromium, nickel, and magnesium. It also has a low degree of plants biodiversity. Therefore, according to X. chrysanthus and X. melanoxylon, X. novoguneensis has a tremendous potential as a candidate in Phytostructure and Phytoremediation. However, the further investigation is required to reveal the potential and the conservation challenge of this plant in Papua.
\end{abstract}

Key words: phytoremediation, phytostructure, open green space area, X. chrysanthus, Potential.

\section{PENDAHULUAN}

Papua merupakan pulau terbesar kedua di dunia setelah Greenland, diketahui memiliki tingkat endemisitas dan biodiversitas tumbuhan yang sangat tinggi (Muller, 2005). X. novoguineenis merupakan jenis tumbuhan endemik terbatas yang hanya ditemukan di Papua dikenal dengan

\footnotetext{
* Alamat korespondensi:

Program Studi Teknik Lingkungan, Universitas Sains dan Teknologi Jayapura (USTJ), Papua. Jl. Raya Padang Bulan, Abepura, Jayapura, Papua, Indonesia 99351. e-mail: raynardsanito@gmail.com
}

nama lokal Sowang (Wilujeng \& Simbiak, 2015). Hingga saat ini, tumbuhan tersebut merupakan satu-satunya dari jenis Xanthostemon yang telah dilaporkan berasal dari Papua (Wilujeng \& Simbiak, 2015). Penyebaran Jenis Xanthostemon dimulai dari Filipina, Indonesia, Australia, Kaledonia Baru hingga Kepulauan Solomon (Sedayu, 2008; Wilson \& Pitispoa, 2007; Wilujeng \& Simbiak, 2015). Di Indonesia, terdapat 4 jenis Xanthostemon yang sudah dilaporkan yaitu: $X$. confertiflorus, $X$. petiolatus, $X$. verus dan $X$. natunae (Merill, 1952; Sosef, 1998; Sedayu, 2008).

Mangkoedihardjo (2011) mengemukakan bahwa terminologi tanaman digunakan untuk 
kebutuhan pangan sedangkan terminologi tumbuhan digunakan dalam lingkungan yang dapat diterjemahkan fitoteknologi. Mangkoedihardjo (2016) juga mengemukakan bahwa berbagai jenis tumbuhan dapat digunakan dalam fitoteknologi karena merupakan salah satu alternatif pilihan yang efektif, mudah, dan murah dalam mengurangi kontaminan pada media lingkungan seperti air, tanah, dan udara. Selain itu, setiap jenis tumbuhan memiliki kemampuan untuk menyerap dan kontaminan melalui akar dan menyimpan kontaminan tersebut pada bagian tubuh tumbuhan. Hanya saja, kemampuan setiap jenis tumbuhan dalam menyerap tumbuhan berbeda-beda. Penggunaan tumbuhan dalam perspektif fitoteknologi secara luas berhubungan dengan fitoremediasi, fitostruktur ruang terbuka hijau, dan fitoforensik logam berat.

Jenis $X$. novoguineensis sebagai tumbuhan endemik Papua, berpotensi dimanfaatkan dalam fitoremediasi lingkungan tercemar dan fitostruktur ruang terbuka hijau pada wilayah perkotaan. Jenis Xanthostemon yang telah diteliti dalam fitoteknologi dan fitostruktur ruang terbuka hijau yaitu X. chrysanthus. Sebagai perbandingan, Ma et al. (2015) mengemukakan bahwa $X$. chrysanthus merupakan tumbuhan yang memiliki ketahanan terhadap kondisi tanah yang asam dan mengindikasikan terjadinya penambahan biomasa. Hal tersebut dipertegas oleh Nazarudin et al. (2015) bahwa jenis X. chrysanthus sangat toleran pada habitat dengan kelembaban tanah yang sangat rendah dan kering.

Walaupun belum terdapat penelitian secara spesifik mengenai $X$. novoguineenis dalam fitoteknologi, tumbuhan tersebut memiliki potensi untuk dimanfaatkan dalam bidang fitoremediasi dan fitostruktur ruang terbuka hijau seperti $X$. chrysanthus. Namun, penelitian lebih lanjut diperlukan untuk membuktikan hal tersebut.

Tujuan dari penulisan artikel ini adalah mengkaji potensi dari $X$. novoguineenis berdasarkan perspektif fitoteknologi sebagai alternatif teknologi pemulihan lingkungan tercemar. Kemudian, potensi perspektif fitoteknologi berdasarkan infrastruktur ruang terbuka hijau dengan menggunakan tumbuhan dari famili Myrtaceae (genus Xanthostemon) sangat potensial untuk diterapkan di Papua. Potensi perspektif fitoteknologi $X$. novoguineenis $\mathrm{di}$ diskusikan dalam artikel ini.

\section{DESKRIPSI TUMBUHAN $X$. novoguineensis}

Tumbuhan X. novoguineensis secara morfologi dapat dikenali dengan bunga yang berwarna merah, tangkai sari yang panjang, dasar buah menyatu dengan hipantium, daun tunggal dan biji berbentuk pipih, ringan, tidak berbulu dan tidak bersayap (Wilujeng \& Simbiak, 2015).

$X$. novoguineenis digolongkan dalam famili Myrtaceae. Di Papua, tumbuhan tersebut dikenal dengan nama lokal Sowang (Mumbo 2010; Sanito, 2016; Sanito, 2017). X. novoguineenis tersebar di Cagar Alam Pegunungan Cyclops dan pada sekitar kaki bukit yang berdekatan dengan danau Sentani dalam bentuk semak dan pohon (Wilujeng \& Simbiak, 2015; Sanito, 2016). Tinggi pohon dapat mencapai $40 \mathrm{~m}$ dengan diameter mencapai $80 \mathrm{~cm}$ (Wilujeng \& Simbiak, 2015). Tumbuhan tersebut tumbuh pada tanah yang cenderung kering dan gersang. Beberapa kaki bukit disekitar Cagar Alam Pegunungan Cyclops memiliki tipe tanah yang berwarna merah, cenderung mirip dengan tanah laterit, dan tanah podsolik.

Menurut Wilujeng \& Simbiak (2015), tumbuhan tersebut merupakan satu-satunya jenis Xanthostemon yang telah dilaporkan dari Papua. Wilujeng \& Simbiak (2015), berpendapat bahwa X. novoguineensis dan X. melanoxylon dari Kepulauan Solomon memiliki kemiripan secara morfologi. Namun, penelitian lebih lanjut perlu dilakukan untuk menghasilkan data yang lebih akurat. Wilson \& Pitisopa (2007), juga mengemukakan bahwa $X$. novoguineenis memiliki kemiripan dengan $X$. melanoxylon dari Kepulauan Solomon. Namun menariknya, bentuk daun dari masingmasing jenis tersebut cenderung berbeda meskipun memiliki warna bunga yang sama. X. novoguineenis juga memiliki kemiripan bunga dengan $X$. verdugonianus dari Filipina. 


\section{POTENSI X. novoguineensis DALAM FITOREMEDIASI}

Penggunaan tumbuhan dalam remediasi lingkungan tercemar pada prinsipnya lebih murah jika dibandingkan dengan teknologi lainnya. Pada konteks fitoremediasi, tumbuhan dan mikroorganisme pada akar mampu menyerap dan mengeliminasi kontaminan dari lingkungan seperti air, tanah, dan udara. Semua jenis tumbuhan dapat digunakan dalam remediasi lingkungan tercemar karena mampu untuk menyimpan kontaminan pada bagian tumbuhan tersebut seperti akar, batang, dan daun. Namun, setiap kemampuan tumbuhan dalam menyerap kontaminan berbeda karena ada tang cepat da nada pula yang cenderung lambat (Mangkoedihardjo, 2016).

Beberapa jenis tumbuhan dari famili Myrtaceae telah diteliti dan digunakan dalam remediasi lingkungan tercemar. Beberapa genus tumbuhan seperti Calycorectes, Campomanesia, Eugenia, Eucalyptus, Melaleuca, Psidium, Syzygium, and Xanthostemon. Hal ini dapat diartikan bahwa jenis endemik Papua, X. novoguineensis berpotensi untuk digunakan dalam remediasi lingkungan tercemar karena masih satu genus dengan Xanthostemon lainnya. Famili dari tumbuhan Myrtaceae cenderung memiliki kemampuan dalam menyerap kontaminan (Tabel 1).

$X$. novoguineenis memiliki potensi untuk digunakan dalam fitoremediasi. Wilujeng \& Simbiak (2015), melaporkan bahwa daun dari tumbuhan tersebut memiliki intervenium yang menunjukkan adaptasi tumbuhan pada habitat kering. Sebagai perbandingan, $X$. chrysanthus diketahui sangat baik dalam menoleransi tanah dengan kelembaban yang sangat rendah, kurang subur, dan kering (Nazarudin et al., 2015). Ma et al. (2015) melakukan eksperimen dengan menanam $X$. chrysanthus pada tanah dengan kondisi asam pada pH 2-2,5. Menariknya, tumbuhan tersebut toleran pada kondisi tanah dengan rentang $\mathrm{pH}$ 2-2,5. Hasil investigasi dari Wilson \& Pitisopa (2007), diperoleh bahwa X. melanoxylon yang merupakan tumbuhan endemik yang ditemukan di Kepulauan Solomon, tumbuh pada kondisi tanah ultrafamik yang pada umumnya memiliki konsentrasi logam berat yang tinggi seperti kromium, nikel, dan magnesium.

Menurut Wilson \& Pitisopa (2007), X. melanoxylon diketahui tumbuh pada dataran rendah dengan tingkat biodiversitas yang rendah.

Keanekaragaman jenis tumbuhan yang

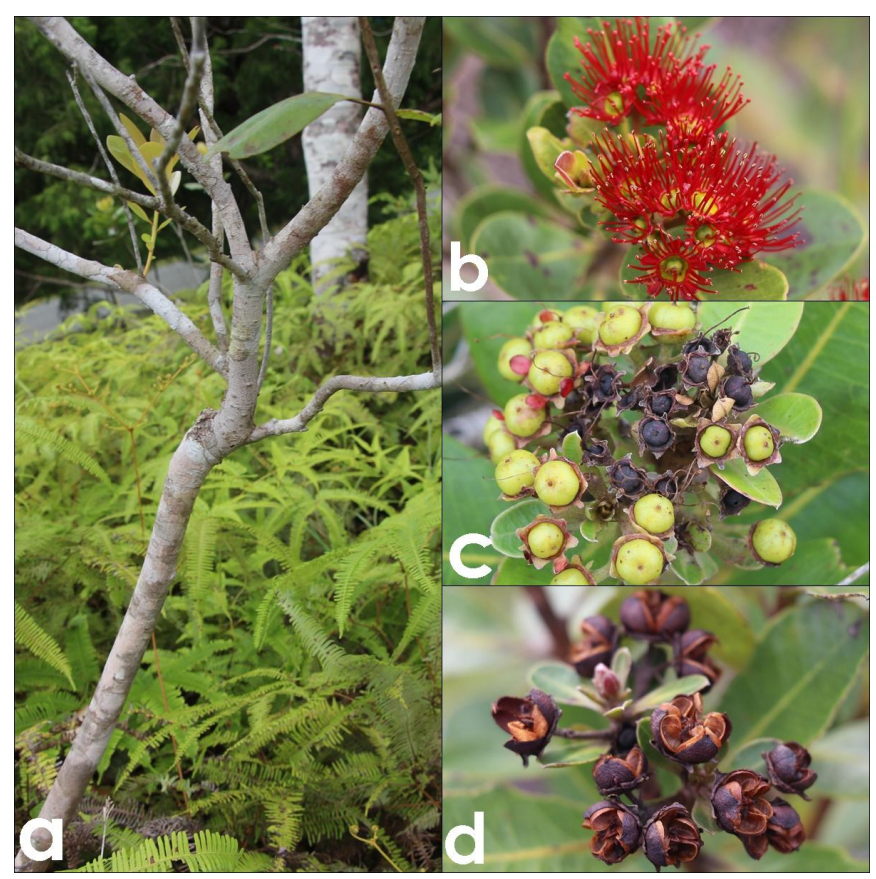

Gambar 1. Jenis X. novoguineenis. (a). Batang pada tumbuhan masih dalam bentuk perdu, (b). warna bunga, (c). morfologi buah, dan (d). Buah yang telah masak dan pecah.

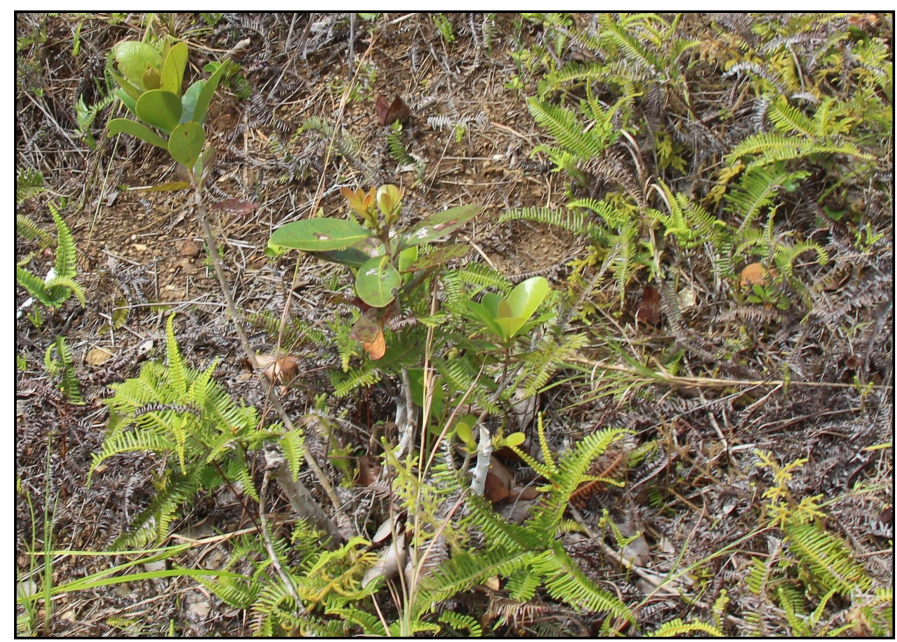

Gambar 2. Tumbuhan X. novoguineenis yang tumbuh pada tanah laterit. 
tumbuh bersamaan pada area tumbuhnya $X$. melanoxylon didominasi oleh Gymnostoma papuanum dan Dillenia crenata. Namun, $X$. melanoxylon tidak tumbuh pada seluruh area hutan. Terdapat beberapa jenis tumbuhan lainnya yang tumbuh secara alami pada tanah ultrafamik seperti Hydriastele hambronii, Myrtekka beccari, dan Pandanus lamprocephalus (Wilson \& Pitisopa, 2007).

$X$. novoguineenis ditemukan tumbuh di tanah laterit atau podsolik yang cenderung kering pada kaki bukit sekitar Cagar Alam Pegunungan Cyclops. Biodiversitas tumbuhan yang tumbuh secara alami berdampingan dengan tumbuhan tersebut diantaranya adalah Kantong Semar (Nephentes sp), Anggrek Tanah (Spathoglotis pilicata), Jarong atau Pecut Kuda berbunga ungu (Stachytarpheta jamaicensis), Jarong berbunga merah muda (Stachytarpheta sp), Nusa Indah (Mussaenda pubescens), Alang-alang (Imperata cylindrica), Harendong atau Kluruk (Melastoma sp), Ketul (Biden spilosa), Rumput Bermuda (Cynodon dactylon), Paku Andam (Dicranopteris linearis), dan Cemara (Casuarina sp). Yawan (2007), melaporkan bahwa berbagai jenis tumbuhan tingkat tinggi yang berasosiasi dengan $X$. novoguineensis yaitu Xanthomyrtus sp, Stenocarpus sp, dan Decaspermum parviflorum diperbukitan sekitar Cagar alam Pegunungan Cyclops.

\section{POTENSI $X$. novoguineensis DALAM FITOSTRUKTUR RUANG TERBUKA HIJAU}

Ruang terbuka hijau merupakan area yang memanjang atau jalur yang mengelompok dimana penggunaannya bersifat terbuka, tempat tumbuhnya tanaman secara alami maupun sengaja ditanam (Undang-undang Republik Indonesia, 2007). Menurut Peraturan Menteri Pekerjaan Umum (2008), penyediaan dan pemanfaatan Ruang Terbuka Hijau (RTH) pada kawasan perkotaan memiliki tujuan yaitu:

a. Menjaga ketersediaan lahan sebagai kawasan resapan air.

b. Menciptakan aspek planologis perkotaan melalui keseimbangan antara lingkungan alam dan lingkungan binaan yang berguna untuk

Tabel 1. Peran tumbuhan Famili Myrtaceae dalam remediasi lingkungan tercemar.

\begin{tabular}{|c|c|c|c|c|}
\hline No & Famili Myrtaceae & $\begin{array}{l}\text { Aplikasi dalam } \\
\text { Fitoteknologi }\end{array}$ & $\begin{array}{c}\text { Fungsi dalam Menyerap } \\
\text { Kontaminan }\end{array}$ & Referensi \\
\hline 1. & Calycorectes acutatus & Fitoremediasi & Remediasi tanah tercemar uranium & Baretto et al. (2011) \\
\hline 2. & Campomanesia xanthocarpa & Fitoremediasi & Remediasi tanah tercemar uranium & Baretto et al., 2011 \\
\hline 3. & Eugenia involucrata & Fitoremediasi & Remediasi tanah tercemar uranium & Baretto et al., 2011 \\
\hline 4. & Eugenia pyriformis & Fitoremediasi & Remediasi tanah tercemar uranium & Baretto et al., 2011 \\
\hline 5. & Eugenia uniflora & Fitoremediasi & Remediasi tanah tercemar uranium & Baretto et al., 2011 \\
\hline 6. & Myrciaria trunciflora & Fitoremediasi & Remediasi tanah tercemar uranium & Baretto et al., 2011 \\
\hline 7. & Psidium cattleianum & Fitoremediasi & Remediasi tanah tercemar uranium & Baretto et al., 2011 \\
\hline 8. & Psidium guajava & Fitoremediasi & Remediasi tanah tercemar uranium & Baretto et al., 2011 \\
\hline 9. & Psidiun myrtoides & Fitoremediasi & Remediasi tanah tercemar uranium & Baretto et al., 2011 \\
\hline 10. & Eucalyptus globulus & Fitoremediasi & $\mathrm{Ag}, \mathrm{Co}, \mathrm{Cr}, \mathrm{Cu}, \mathrm{Fe}, \mathrm{Ni}, \mathrm{Pb}$ dan $\mathrm{Zn}$ & Pratas et al, 2013 \\
\hline 11. & Eucalyptus camaldulensis & Fitoremediasi & $\mathrm{Cd}, \mathrm{Pb}, \mathrm{Ni}$, and $\mathrm{As}$ & Ortega et al, 2010 \\
\hline 12. & Xanthostemon chrysanthus & Fitoremediasi & $\begin{array}{l}\text { Tahan terhadap kondisi asam } \\
(\mathrm{pH} 2-2,5)\end{array}$ & Ma et al., 2015 \\
\hline 13. & Syzygium hainanense & Fitoremediasi & $\begin{array}{l}\text { Tahan terhadap kondisi asam } \\
(\mathrm{pH} 2-2,5)\end{array}$ & $\begin{array}{l}\text { Ma et al., 2015, Schmitt } \\
\text { et al., } 2015 .\end{array}$ \\
\hline 14. & Melaleuca cajuputi & Fitoremediasi & $\mathrm{Zn}, \mathrm{Cd}$, dan $\mathrm{Cu}$ & Mohd et al., 2013 \\
\hline 15. & Eucalyptus viminalis & Fitoremediasi & $\begin{array}{l}\text { Tahan terhadap kondisi asam } \\
(\mathrm{pH} 2-2,5)\end{array}$ & $\begin{array}{l}\text { Ma et al., 2015, Schmitt } \\
\text { et al., } 2015 .\end{array}$ \\
\hline
\end{tabular}


kepentingan masyarakat.

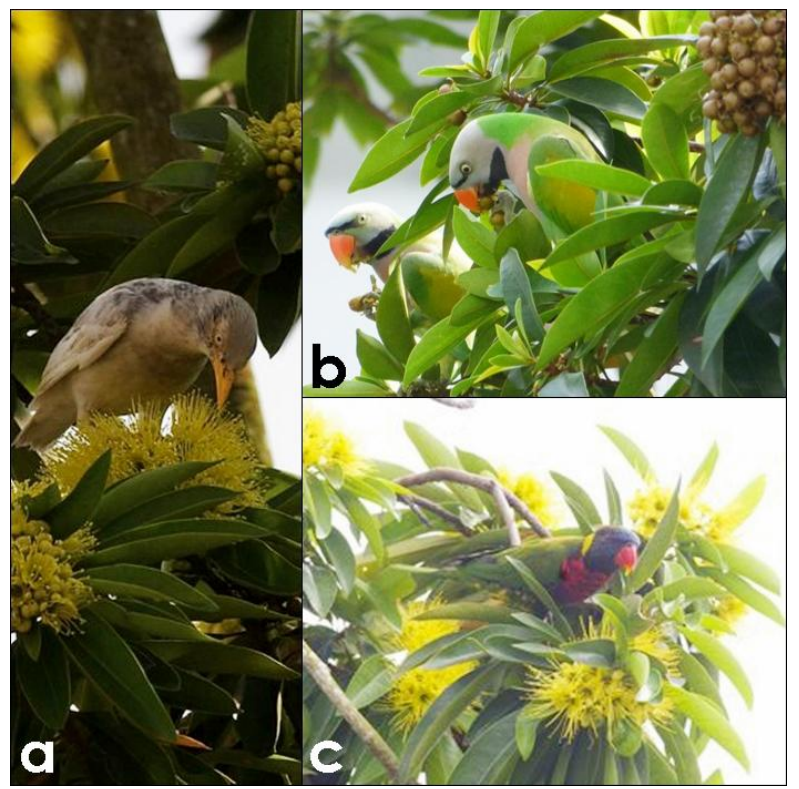

Gambar 3. Jenis-jenis burung yang mengkonsumsi nektar dan buah $X$. chrysanthus. (a). Jalak (Acroditheres javanicus) sedang menghisap nektar bunga (Amar-Sing \& Wae, 2011), (b). Betet (Psittacula alexandri) sedang memakan buah X. chrysanthus (Ling \& Hui, 2016), (c). Nektar X. chrysanthus menjadi sumber pakan bagi Perkici Pelangi (Trichoglossus haematodus) (Amar-Sing \& Wae, 2011).

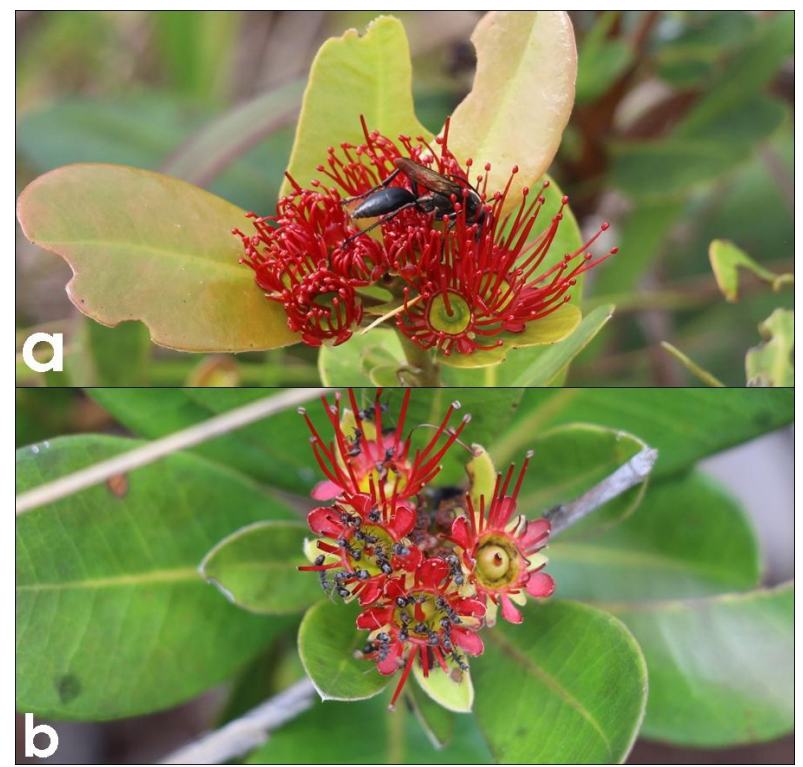

Gambar 4. Serangga yang berasosiasi dengan $X$. novoguineensis (a). Jenis Tawon Hitam (Hymnoptera) sedang mengisap nektar, (b). Koloni semut hitam yang menghisap nektar sebagai sumber makanan utama. c. Meningkatkan keserasian lingkungan perkotaan sebagai sarana pengaman lingkungan perkotaan yang aman, nyaman, segar, indah, dan bersih.

Menurut Peraturan Menteri Pekerjaan Umum (2008), ruang terbuka hijau memiliki berbagai fungsi yaitu:

a. Fungsi utama (intrinsik) merupakan fungsi ekologis yaitu memberi jaminan pengadaan RTH menjadi bagian dari sistem sirkulasi udara (paru-paru kota), pengatur iklim mikro agar sirkulasi udara dan air secara alami dapat berlangsung lancar, sebagai peneduh, produsen oksigen, penyerap air hujan, penyedia habitat satwa, penyerap polutan media udara, air, tanah, dan penahan angin.

b. Fungsi tambahan (ekstrinsik) diantaranya yaitu:

1) Fungsi sosial dan budaya diantaranya adalah menggambarkan ekspresi budaya lokal, media komunikasi warga kota, tempat rekreasi wadah dan objek pendidikan, penelitian, dan pelatihan dalam mempelajari alam.

2) Fungsi ekonomi sebagai sumber produk yang bisa di jual, seperti tanaman bunga buah daun dan sayur bahkan dapat menjadi bagian dari usaha pertanian, perkebunan, kehutanan, dan lain-lain.

3) Fungsi estetika untuk meningkatkan kenyamanan dan memperindah lingkungan kota baik dari skala mikro seperti halaman rumah, lingkungan permukiman, maupun makro seperti lansekap dan kota secara keseluruhan. Selain itu, pembangunan Ruang Terbuka Hijau (RTH) juga menciptakan suasana serasi dan seimbang antara area terbangun dan belum terbangun.

$X$. novoguineenis memiliki potensi yang sama dengan $X$. chrysanthus karena masih tergolong dalam genus dan famili yang sama, dan khususnya dalam kajian fitorstruktur ruang terbuka hijau. Wilujeng \& Simbiak (2015), melaporkan bahwa daun dari $X$. novoguineenis memiliki intervenium yang pada prinsipnya menunjukkan proses adaptasi tumbuhan tersebut pada habitat yang cenderung kering. Nazarudin et al. (2015) mengemukakan bahwa Xanthostemon sangat baik dalam toleransi tanah dengan 
kelembaban yang sangat rendah, kurang subur dan penetrasi tanah yang tinggi.

Sebagai acuan, X. chrysanthus merupakan jenis tumbuhan yang ditemukan di Australia pada negara bagian Queensland dan menyebar dari daerah Townsville hingga Cape York (Australia Plants Society, 2017). Meskipun belum terdapat laporan mengenai penggunaan $X$. novoguineenis dalam fitostruktur ruang terbuka hijau di Papua, $X$. chrysanthus telah ditanam pada infrastruktur ruang terbuka hijau publik di Malaysia dan ruang terbuka hijau privat di Singapura (Nazarudin et al., 2015; Ling \& Hui, 2016). Nazarudin et al. (2015) mengemukakan bahwa di Malaysia, tumbuhan tersebut telah ditanam pada daerah Metropolitan Batu Park dan Pusar Bandar Manjalara. Di Singapura, tumbuhan tersebut ditemukan telah ditanam pada ruang terbuka hijau privat pada sebuah kompleks Apartemen (Ling \& Hui, 2016). Menariknya, secara tidak langsung $X$. chrysanthus telah memberikan kontribusi berupa fungsi ekologi dimana menjadi nursery ground dengan menyediakan sumber pakan bagi jenis burung. Betet (Psittacula alexandri) merupakan jenis burung yang diketahui memakan buah dari X. chrysanthus yang ditanam pada ruang terbuka hijau publik (Ling \& Hui, 2016). Amar-Sing \& Wae (2011), melaporkan bahwa jenis-jenis burung seperti Jalak (Acroditheres javanicus), Merbah Cerukcuk (Phyconotus golavier), Burung Madu Kelapa (Anthereptes malacensis), Serindit Melayu atau Bluecrowned hanging Parrots (Loricukus galgulus), dan Perkici Pelangi atau Rainbow Lorikeet (Trichoglossus haematodus) menghisap nektar dari bunga $X$. chrysanthus. Diperlukan penelitian lebih lanjut untuk mengetahui apakah buah dari $X$. novoguineenis dapat menjadi sumber pakan utama bagi berbagai jenis burung yang terdapat di Papua.

Nektar dari bunga $X$. novoguineenis juga diketahui menjadi sumber pakan bagi beberapa jenis serangga. Beberapa jenis serangga telah diketahui mengonsumi nektar dari tumbuhan tersebut. Jenis serangga seperti Tawon Hitam (ordo Hymenoptera) dan Semut Hitam (famili Formicidae) merupakan jenis serangga yang memakan nektar dari tumbuhan tersebut. Peranan berbagai jenis serangga tersebut perlu diteliti lebih lanjut dalam ekologi $X$. novoguineenis.

Menurut Nazarudin et al. (2014) daya tahan X. chrysanthus dalam penetrasi kedalam lapisan tanah adalah 2,9 Mpa, dengan kondisi kelembaban tanah yang cenderung kurang, dan kesuburan tanah yang rendah. Studi dari Sinnet et al. (2008) mengindikasikan bahwa nilai ketahanan penetrasi akar tumbuhan baik pada rentang 2-3 MPa. Nazarudin (2016), berpendapat bahwa tumbuhan tersebut merupakan kandidat utama sebagai tanaman perkotaan atau urban planting di Malaysia.

Ludang et al. (2011) melakukan wawancara dan penyebaran kuisioner langsung pada responden lokal, khususnya Suku Dayak yang telah tinggal 2-3 generasi yang menetap pada suatu wilayah, dan tidak hidup bersama dengan suku lainnya. Wawancara dilakukan untuk menentukan pemilihan jenis tumbuhan asli yang digunakan dalam fitostruktur ruang terbuka hijau publik di Kota Palangka Raya, Kalimantan Tengah menurut pengetahuan asli mereka. Beberapa jenis tumbuhan asli Palangka Raya yang menurut mereka cocok untuk digunakan dalam ruang terbuka hijau publik diantaranya adalah Nangka (Artocarpus heterophyllus) sebagai fungsi ekonomi, Pinang Merah (Chrtostachys lakka), Kenanga (Cananga odorata) sebagai fungsi estetika dan tanaman hias, dan Serai (Cymbopo gene citrates) yang juga dapat digunakan sebagai fungsi ekonomi dan digunakan sebagai tanaman pangan. Pemilihan tumbuhan lokal berdasarkan pengetahuan Suku Dayak untuk fitostruktur ruang terbuka hijau merupakan bentuk penerapan fungsi sosial budaya dalam pembangunan ruang terbuka hijau. $X$. novoguineenis berpotensi untuk digunakan dalam merepresentasikan aspek sosial budaya dari Suku Sentani karena telah dikenal berdasarkan folk taksonomi.

Secara prinsip, X. novoguineenis dapat dipilih sebagai tumbuhan yang digunakan dalam infrastruktur ruang terbuka hijau karena merepresentasikan hubungan sosial budaya Suku Sentani dengan alam. Secara etnobotani, kayu dari $X$. novoguineenis digunakan sebagai fondasi rumah, alat perkakas dan peralatan makan karena 
struktur kayu yang keras dan awet. Kayu dari tumbuhan tersebut juga diukir dan dipasang pada rumah kepala suku atau kepala adat untuk melambangkan kekuasaan di kampung (Mumbo, 2010; Sanito, 2017).

Penanaman berbagai jenis tumbuhan pada pada ruang terbuka hijau sangat baik dalam fungsi ekologis, tidak hanya menyediakan sumber pakan bagi organisme tetapi juga secara khusus mengatur iklim mikro, peneduh, memproduksi oksigen, dan sebagai penyerap berbagai jenis-jenis polutan yang terdapat di tanah, air, dan udara (Peraturan Menteri Pekerjaan Umum, 2008). Setiap jenis tanaman memiliki kemampuan dalam

Tabel 2. Fungsi Potensial X. novoguineenis dalam ruang terbuka hijau dalam fungsi ekologis, fungsi sosial budaya, fungsi ekonomi, dan fungsi estetika.

\begin{tabular}{lccc}
\hline No & $\begin{array}{c}\text { Fungsi ruang terbuka } \\
\text { hijau }\end{array}$ & Potensi X. novoguineenis & Referensi \\
\hline
\end{tabular}

\begin{tabular}{lll}
\hline & & Fungsi Intrinsik \\
\hline $1 .$. & Fungsi ekologis & X. novoguineenis menjadi sumbar pakan bagi beberapa
\end{tabular}
satwa, khususnya nektar yang berasal dari bunga dimana menjadi daya tarik bagi serangga seperti semut, kupu-kupu dan lebah. Daun menjadi sumber pakan serangga tertentu, meskipun belum diketahui

Artikel Ini jenis-jenis serangga yang memakan daun dari tumbuhan tersebut. Selain itu, juga berperan dalam konservasi tumbuhan.

Walaupun belum terdapat bukti ilmiah bahwa buah dari $X$. novoguineenis menjadi sumber pakan bagi unggas, $X$. chrysanthus yang ditanam pada ruang terbuka publik di Singapura diketahui menjadi sumber pakan bagi burung. Di Malaysia, X. chrysanthus juga telah ditanam pada Ruang Terbuka Hijau (RTH) publik.

\section{Fungsi Ekstrinsik}

2. Fungsi sosial budaya

Pemanfaatan $X$. novoguineenis secara tidak langsung juga merepresentasikan budaya Suku Sentani secara turun temurun. Hal tersebut karena kayu dari tumbuhan tersebut telah dimanfaatkan secara tradisional untuk melambangkan status sosial kepala adat dan kepala kampung, pembuatan alat perkakas, Nazarudin et al., (2015) \& Ling \& Hui, (2016) alat makan, dan tiang rumah atau fondasi rumah Suku Sentani yang tinggal di pinggiran Danau Sentani.

3. Fungsi ekonomi Selain Kayu X. novoguineenis yang dimanfaatkan oleh Suku Sentani, hingga saat ini belum terdapat informasi atau belum diketahui mengenai pemanfaatan buah dan daun dari $X$. novoguineenis untuk dikonsumsi oleh manusia sebagai tanaman pangan.

4. Fungsi estetika Bunga dari jenis Xanthostemon cenderung berbunga sepanjang tahun. Selanjutnya, bunga dari $X$. novoguineenis terlihat menyolok dan indah dengan jumlah benang sari yang memanjang seperti jenis xanthostemon lainnya. Contoh dari Xanthostemon tersebut misalnya: X. chrysanthus, X. melanoxylon, $X$. youngii, $X$. verdugonianus, dan jenis Xanthostemon Mumbo (2010), Wilujeng \& Simbiak (2015), Sanito (2017).

Mumbo (2010).

Peraturan Menteri Pekerjaan Umum (2008). lainnya. Jika digunakan sebagai tanaman hias dapat memperindah lansekap dan taman kota. 
Tabel 3. Tumbuh-tumbuhan dari famili Myrtaceae yang telah diteliti dalam remediasi udara tercemar (Takashi \& Morikawa, 2012).

\begin{tabular}{|c|c|c|c|c|}
\hline \multirow[t]{2}{*}{ No } & \multirow[t]{2}{*}{ Famili Myrtaceae } & \multirow{2}{*}{$\begin{array}{l}\text { Aplikasi dalam } \\
\text { fitoteknologi }\end{array}$} & \multicolumn{2}{|c|}{$\mathrm{NO}_{2}\left(\mathrm{RNNO}_{2}\right)$} \\
\hline & & & $\begin{array}{c}\mathrm{RNNO}_{2} \\
(\mathrm{mgN} / \mathrm{g} \text { dry wt) }\end{array}$ & $\begin{array}{c}\mathrm{RNNO}_{2} / \mathrm{RN} \\
(\%)\end{array}$ \\
\hline 1. & Eucalyptus grandis & Fitostruktur & 4,57 & 8,5 \\
\hline 2. & Eucalyptus globulus & Fitostruktur & 4,08 & 9,4 \\
\hline 3. & Eucalyptus viminalis & Fitostruktur & 6,57 & 12,5 \\
\hline
\end{tabular}

menyerap dan menyimpan kontaminan pada bagian tumbuhan itu sendiri secara langsung (Mangkoedihardjo, 2016). Fungsi sosial budaya berhubungan dengan pemanfaatan tumbuhan tersebut secara tradisional dan persepsi suku tertentu, sedangkan fungsi estetika berhubungan dengan keindahan tumbuhan itu sendiri (Tabel 2).

Tumbuhan dari famili Myrtaceae secara garis besar diketahui telah ditanam dalam fitostruktur ruang terbuka hijau. Takahashi \& Morikawa (2012), melaporkan bahwa beberapa jenis tumbuhan seperti: Eucalyptus grandis, E. globulus, dan $E$. viminalis mampu menyerap nitrogen oksida $\left(\mathrm{NO}_{2} / \mathrm{RNNO}_{2}\right)$ dengan konsentrasi masingmasing kontaminan sebesar 6,57 $\mathrm{mgN} / \mathrm{g}$, 4,57 $\mathrm{mgN} / \mathrm{g}$ dan 4,08 mgN/g (Tabel 3).

\section{TANTANGAN PENERAPAN $X$. novoguineensis DALAM FITOTEKNOLOGI DI PAPUA}

Pemanfaatan $X$. novoguineenis dalam ruang terbuka hijau publik dan remediasi lingkungan tercemar di Papua merupakan suatu tantangan tersendiri. Tumbuhan tersebut hingga saat ini cukup sulit ditemukan dalam bentuk tegakan. Hasil eksplorasi oleh Wilujeng \& Simbiak (2015) pada daerah disekitar Cagar Alam Pegunungan Cyclops dan Kaki Bukit di daerah Doyo Baru dan Kamp Walker, diketahui bahwa $X$. novoguineenis di alam lebih didominasi oleh semak dibandingkan tegakan. Wilujeng \& Simbiak (2015) menambahan bahwa faktor-faktor yang berpengaruh pada sulitnya tegakan tumbuhan tersebut ditemukan karena penebangan pohon untuk digunakan kayunya, fragmentasi habitat, dan daya pertumbuhan di alam yang rendah.

Konservasi X. novoguineenis perlu diupayakan dengan tujuan mencegah tumbuhan tersebut agar tidak punah sebelum dapat dimanfaatkan dan diteliti lebih jauh. Peluang konservasi tumbuhan tersebut berdasarkan analisis SWOT dapat dilaksanakan dengan memanfaatkan berbagai peluang dan kekuatan yang ada karena memiliki nilai sosial budaya, nilai etnobotani, merupakan tumbuhan endemik di Papua, dan bernilai ekonomi tinggi (Sanito, 2016).

$X$. novoguineensis juga berpotensi untuk digunakan dalam fitoremediasi dan fitorstruktur ruang terbuka hijau di Papua. Habitat alami dari tumbuhan tersebut pada tanah laterit dan tanah podsolik atau tanah merah yang kurang subur dapat menjadi pertimbangan utama. Kemudian, penggunaan tumbuhan pada tanah tercemar logam berat dan kondisi asam patut untuk di investigasi lebih lanjut. Laporan-laporan mengenai peranan tumbuhan asli dan endemik di Papua memiliki nilai sosial budaya serta ekologi dapat dipertimbangkan dalam fitostruktur ruang terbuka hijau. Hanya saja, penelitian lebih lanjut mengenai fungsi tersebut perlu dilakukan secara akurat dan berkelanjutan.

\section{KESIMPULAN}

Berdasarkan berbagi hasil kajian literatur, $X$. novoguineensis memiliki potensi untuk digunakan dalam bidang fitoteknologi, khususnya fitoremediasi dan fitostruktur ruang terbuka hijau di Papua. Namun, penelitian lebih lanjut perlu 
dilakukan untuk mengungkap lebih jauh mengenai berbagai potensi tersebut. Kemudian, konservasi $X$. novoguineensis juga perlu diupayakan untuk mencegah terjadinya kepunahan sebelum tumbuhan tersebut dapat dimanfaatkan dan diteliti lebih lanjut. Hal ini disebabkan karena sulitnya menemukan $X$. novoguineensis pada habitat alaminya.

\section{DAFTAR PUSTAKA}

Amar-Singh, H.S. S., and Y.J. Wee. 2011. Golden penda (Xanthostemon chrysanthus) and nectar feeders. Bird Ecology Study Group. (http://www.besgroup.org/2011/ 03/30/golden-penda-xanthostemon-chrysanthus-andnectar-feeders/), diakses 28 November 2017.

Australian Native Plants Society. 2017. Xanthosthemon chrysanthus: general description. (Online) (http://anpsa.org.au/x-chr.html), diakses: 28 November 2017.

Barreto, H.M, W.D.S. Pereira., A. Kelecoma, C. Goncalves., and G.T.D. Oliveira. 2011. Recovery of an area degraded by uranium mining using phytoremediation. International Nuclear Atlantic Conference-INAC. ISBN: 978-85-99141-04-5.

Fonseca, G., H. Barreto., W.S.Pereira., A. Kelecom., Goncalves., dan de Oliveira. 2011. "Recovery of an area degraded by uranium mining using phytoremediation'. International Nuclear Atlantic Conference. ISBN: 978-85-99141-04-5.

Ling, K.L. dan T.H. Hui. 2016. Red-breasted parakeets eating golden penda fruits. Singapore Biodiversity Records 2016. 168. ISSN 2345-7597.

Ludang, Y., S. Mangkoedihardjo., W. Hadi., dan S. Jarias. 2011. Biodiversity of city phytostructure by incorporating indigenous knowledge for the city of Palangka Raya, Indonesia. International Journal of Academic Research. 3(6): 289-292.

Ma, L., R. Rao., P. Lu, S. Huang., X. Chen., Z. Xu., dan J. Xie. 2015. Acid-tolerant plant species screened for rehabilitating acid mine drainage sites. Journal of Soil Sediments. 15: 1104-1112.

Mangkoedihardjo, S. 2007. Phytotechnology integrity in environmental sanitation for sustainable development. Journal of Applied Science Research, INSInet Publication. 3(10): 1037-1044.

Mangkoedihardjo, S. 2011. Applied phytotechnology in environmental sanitation for the tropics and the ocean countries. Emerging Issues in The Natural and Applied Sciences. Baku, Azerbaijan. ISBN 978-9952-8071-4-1.

Mangkoedihardjo, S. 2016. Phytotechnology for bioremediation of contaminated soils-the essential conditions for mixed plants. Proceeding of $3^{\text {rd }}$ International Postgraduate Conference on Biotechnology. pp: 23-24.

Merill, E.D. 1952. Notes on Xanthostemon F. Mueller and Kjellbergiodendron Burret. Journal of Arnold Arboretum. 33 150-161.
Muller, K. 2005. Keragaman hayati tanah Papua. Universitas Negeri Papua. Manokwari.

Mumbo, E, M. 2010. Etnobotani kayu Sowang (Xanthosthemon sp) pada masyarakat Kampung Doyo Lama dan Kampung Harapan di kawasan Cagar Alam Pegunugan Cyclops Kabupaten Jayapura. [Skripsi]. Universitas Cenderawasih. Jayapura.

Mohd, N.S., N.M. Majid, N.A.M. Shazili, and A. Abdu. 2013. Growth performance, biomass and phytoextraction efficiency of Acacia mangium and Melaleuca cajuputi in remediating heavy metal contaminated soil. American Journal of Environmental Science. 9(4): 310-316.

Nazarudin, A.M.R., F.Y. Tsan., O. Normaniza, and Y. Adzmi. 2014. Growth performance and flowering of Xanthostemon chrysanthus at two urban sites in Kuala Lumpur, Malaysia. Journal of Tropical Forest Science. 26(3): 428-434.

Nazarudin, A.M.R., F.Y. Tsan., and O. Normaniza. 2015. Physiological changes of Xanthostemon chrysanthus as affected by paclobutrazol and potassium nitrate. Proceeding of The International Conference on Plant Physiology 2014. Technology for Sustainable Resources, Malaysia Society of Plant Physiology. Selangor, Malaysia. pp: 88-91.

Nazarudin, M.R. 2016. Xanthostemon chrysanthus (F.Muell). Benth: A new flowering tree for urban landscapes. International Journal of Agriculture, Forestry and Plantation. 3: 50-54.

Ortega-Larrocea, M.D.P., B. Xoconostle., I.E.M. Mendoza., R.C. Gonzales., J.H. Hernandez, M.D. Gardum., M.L. Meyer., L.G. Flores, and M.D.C.A. Chavez. 2010. Plant and fungal biodiversity from metal mine wastes under remediation. Journal of Environmental Pollution. 158: 19221931.

Peraturan Menteri Pekerjaan Umum. 2008. Peraturan Menteri Pekerjaan Umum No 5/PRT/M/2008/ tentang pedoman penyediaan dan pemanfaatan ruang terbuka hijau di kawasan perkotaan. Direktorat Jenderal Penataan Ruang Pekerjaan Umum. Jakarta.

Pratas, J., P.J.C. Favas., R. D'Souza., M. Varun., and M.S. Paul. 2013. Phytoremedial assessment of flora tolerant to heavy metals in the contaminated soils of an Abandoned $\mathrm{Pb}$ Mine in Central Portugal. Journal of Chemosphere. 90: 2216-2225.

Sanito, R.C. 2016. Analisis strategi konservasi Sowang (Xanthostemon sp) di sekitar Danau Sentani dan Cagar Alam Pegunungan Cyclops oleh Suku Sentani. Prosiding Seminar Ilmiah Hasil-hasil Penelitian Papua, Konferensi Internasional Keanekaragaman Hayati, Ekowisata, dan Ekonomi Kreatif, Jayapura. pp.149-159.

Sanito, R.C. 2017. Jenis-jenis tumbuhan lokal yang dimanfaatkan sebagai bahan baku pembuatan peralatan dalam pengolahan sagu (Metroxylon sp). Prosiding Seminar Nasional Pendidikan Biologi dan Saintek, Surakarta. pp:14-20. ISSN: 2527-5333X.

Sinnett, D., G. Morgan, M. William, and T. Hutchings. 2008. Soil penetration resistance and tree root development. Soil Use and Management. 24(3): 273-280. 
Schmitt, M., M.S. Boras., A. Tjoa., T. Watanabe, and S. Jansen. 2016. Aluminium accumulation and intra-tree distribution patterns in three arbor aluminosa (Symplocos) species from Central Sulawesi. PLos ONE. 11(2): $1-18$

Sedayu, A. 2008. A New species of Xanthostemon (Myrtaceae) from Natuna Island, Indonesia. Reinwardtia. 2(5): 447-449.

Sosef, M.S., H.L.T. Hong, and S. Prawiroatmodjo, S. 1998. Plant resources of South East Asia, Timber Trees: LesserKnown Timbers, Prosea Edisi 5(3). Bogor.

Takashaki, M. and H. Morikawa. 2012. Air pollutant philic plants for air remediation. Journal of Environment Protection. 3: 1346-1352.
Undang-undang Republik Indonesia. 2007. Undang-undang Republik Indonesia No 26 Tahun 2007 Tentang Penataan Ruang.

Wilujeng, S dan M. Simbiak. 2015. Karakterisasi morfologi Xanthostemon novoguineensis Valeton (Myrtaceae) dari Papua. Prosiding Seminar Nasional Masyarakat Biodiversitas Indonesia. 1(3): 466-471.

Wilson, P.G and F. Pitisopa. 2007. Xanthostemon melanoxylon (Myrtaceae), a new species from the Solomon Islands. Telopea. 11(4): 339-403.

Yawan, E.C.N. 2007. Ekologi kayu Sowang (Xanthostemon sp) di wilayah Waena Kampung Buper Kawasan Cagar Alam Cyclops Jayapura Papua. [Skripsi]. Universitas Cenderawasih. Jayapura. 